\title{
Arbuscular mycorrhiza and dark septate endophyte fungal associations of Oryza sativa L. under field condition: colonization features and their occurrence
}

\author{
Kripamoy Chakraborty $^{1 *}$, Subam Banik ${ }^{1}$, Atithi Debnath ${ }^{1}$, Aparajita Roy Das ${ }^{2}$, Ajay Krishna Saha ${ }^{2}$, \\ Panna Das $^{1}$
}

${ }^{1}$ Microbiology Laboratory, Department of Botany, Tripura University, Suryamaninagar 799022, Tripura, India

${ }^{2}$ Mycology and Plant Pathology Laboratory, Department of Botany, Tripura University, Suryamaninagar 799022, Tripura, India

\section{Article history}

Received: 04 January 2019

Accepted: 03 February 2019

Published: 17 February 2019

\section{Editor}

Champa P Wijekoon

Canadian Centre for Agri-Food Research in Health and Medicine Manitoba, Canada

\section{Publisher}

Horizon e-Publishing Group

\author{
*Correspondence \\ Kripamoy Chakraborty \\ $\triangle$ kripachakraborty@gmail.com
}

\begin{abstract}
The present study was aimed to study monthly colonization of arbuscular mycorrhizal (AM) and dark septate endophyte (DSE) fungal associations in rice. The presence of mycorrhizal structures in the roots confirms the colonization by AM fungi. The pattern of hyphae and arbuscules denotes Arum type of AM fungal morphology. The presence of dark coloured septate hyphae running frequently on the epidermal layer and in root cortex and the occurrence of microsclerotia marks the colonization by DSE fungi. The co-occurrence of both AM and DSE fungi ensure dual colonization by two distinct fungal groups. There was significant increase in arbuscules, vesicles and hyphal percentages from first to third month in both the samples collected from two sites. In the third month, AM colonization significantly higher in both the sites. DSE colonization percentages do not differ significantly in first to third month. A total of nine AM fungal species were recovered from two sites. This study is an effort to make aware the local farmers about the usefulness of these native AM mycobiota which can be a preferable choice over chemical fertilizers leading to ecofriendly organic farming.
\end{abstract}

Keywords: Rice; AM fungi; DSE; Arum type; AM fungal species

\section{Citation}

Chakraborty K, Banik S, Debnath A, Das AR, Saha AK, Das P. Arbuscular mycorrhiza and dark septate endophyte fungal associations of Oryza sativa L. under field condition: colonization features and their occurrence. Plant Science Today 2019;6(1):63-70. https://doi.org/10.14719/pst.2019.6.1.474

Copyright: (C) Chakraborty et al. (2019). This is an open-access article distributed under the terms of the Creative Commons Attribution License, which permits unrestricted use, distribution, and reproduction in any medium, provided the original author and source are credited (https://creativecommons.org/licenses/by/4.0/).

Indexing: Plant Science Today is covered by Scopus, CAS, AGRIS, CABI, Google Scholar, etc. Full list at http://www.plantsciencetoday.online

\section{Introduction}

Mycorrhizal association between beneficial soil fungi and plant roots are ubiquitous in terrestrial plant communities (1). The colonization of crop plants by arbuscular mycorrhizal (AM) fungi can improve their nutrients uptake predominantly phosphorus and are linked with crop yields $(2,3)$. Based on the occurrence of AM fungal structures within plant roots, AM morphology has been classified as Arum, Paris or intermediate-types (4).

Roots of crop plants are also colonized by a group of melanized, septate fungi known as dark 
septate fungal endophytes (DSE) (5,6). DSE facilitates nutrient uptake of the plant, helps in water uptake and increases stress tolerance (7).

Rice (Oryza sativa L.) is one of the major staple food of Northeast India and flourishly grown throughout India. The rice straw is also used as cattle feed and for making straw boards, mats and papers. Rice bran oil is used for making soap and cosmetics (8). Certain studies revealed that AM fungi root colonization has seasonal dynamics $(9,10)$. Rice plants readily form mycorrhizal associations under upland conditions and limited colonization occurs under submerged conditions due to the anoxic environment (11). Application of mycorrhizal inoculum increased the soil nutrients and root colonization in rice plants (12).

There is no report related to monthly AM and DSE fungal colonization of rice in relation to structural features within the root. In this connection, the present study was focused on the evaluation of AM and DSE fungal colonization and AM fungal composition associated with rice growing in two areas of Tripura, Northeast India.

\section{Materials and methods}

\section{Study sites}

For assessing the AM, DSE fungal colonization and AM fungal composition, root and soil samples were collected regularly at an interval of one month from two selected study sites of Suryamaninagar and Teliamura, Tripura, Northeast India. The study sites of rice field were Suryamaninagar (N $23^{\circ} 46.0^{\prime}$ E $91^{\circ} 16.4^{\prime}, 22$ masl) and Teliamura (N $23^{\circ}$ 56.361' E $91^{\circ} 47.341^{\prime}, 136$ masl) is depicted in Fig. 1. Pooja variety of rice was planted in the rice fields of Suryamaninagar and Teliamura. It is also capable of tolerating water stagnation and suitable for late transplanting with aged seedlings. Urea 10$15 \mathrm{~kg}$ per hectare and DAP $5 \mathrm{~kg}$ per hectare were applied once to the fields during first month after transplanting. The sampling period of roots of the plant and soil was during August to November 2016. This rice variety was collected from the local Block offices by the local farmers. The rice fields were irrigated by canal water. The selected study sites experiences humid tropical climate with $22.68^{\circ} \mathrm{C}, 78.57 \%$, and $18.57 \mathrm{~mm}$ of average temperature, relative humidity and rainfall during the sampling period, respectively.

\section{Root and soil sampling}

The fine root samples of ten randomly selected healthy and disease free paddy plants were harvested from each of the three selected paddy field. The roots were sampled four times i.e, $1^{\text {st }}-4^{\text {th }}$ months after transplanting of seedlings in the field. Root samples were collected by uprooting the plants. The root samples were washed gently to remove the adhering soil and fixed in formalin- acetic acid (FAA) solution and brought to the laboratory for further processing. Soil adhering to the roots and next to plants were collected and mixed to form a composite soil mixture after the fourth month. This composite soil mixture was brought to the laboratory for the assessment of composition and density of AM fungi inhabiting in the rhizosphere of paddy fields.

\section{Assessment of AM and DSE fungal colonization}

Fixed root samples were washed several times in running tap water and cut into approximately 1 $\mathrm{cm}$ in size. Then root segments were cleaned with $10 \% \mathrm{NaOH}$ at $90^{\circ} \mathrm{C}$. The duration of heating depends on the clearance of the root samples. The cleaned roots were again washed with tap water for several times. Then 2-3 drops of hydrogen peroxide $\left(\mathrm{H}_{2} \mathrm{O}_{2}\right)$ were given to the root segments and slightly heated for additional cleaning. After this the root segments were again washed with tap water, the root segments were stained (13). Then the root segments were mounted on lactoglycerol and observed under bright field microscope (Olympus CX21i) for various AM and DSE fungal structures. Aseptate linear and coiled inter or intracellular fungal hyphae accompanied with arbuscules were considered for AM fungal colonization whereas regularly or irregularly septate melanized fungal hyphae along with microsclerotia were taken in account for DSE colonization. The estimation of AM fungi and DSE colonization was done by magnified intersection method (14).

\section{Isolation and identification of AM fungal spores}

The soil brought from the field was cleaned by removing leaf litter and other debris taking utmost care so that the soil attached to the litter and debris were not lost by this process and the AM fungal spores were isolated by Wet Sieving and decanting method of (15). Spores were recovered by filtering the sieved fraction onto a filter paper. The filter paper was then spread over a large petridish $(13.5 \mathrm{~cm})$ and intact spores were counted according to morphologically distinct types and recorded as total per sample in $50 \mathrm{~g}$ soil as spore density under a dissecting microscope. The collection of intact spore types from the petri dish and slides were prepared and pinpointing features were recorded for the identification of AM fungi. The spores were then mounted on glass slides in polyvinyl-lactic acid and carefully crushed under a dissecting microscope (16). Taxonomic identification of these spores was done on the basis of spore morphology, subcellular characters and ornamentation in the spore wall. Spore characters were compared with the original descriptions (www.amf-phylogeny.com). The fieldcollected spores are generally unreliable due to the lack of fine taxonomic characters or presence of inadequate number of spores. Therefore, the identification of AM fungal spores was restricted 

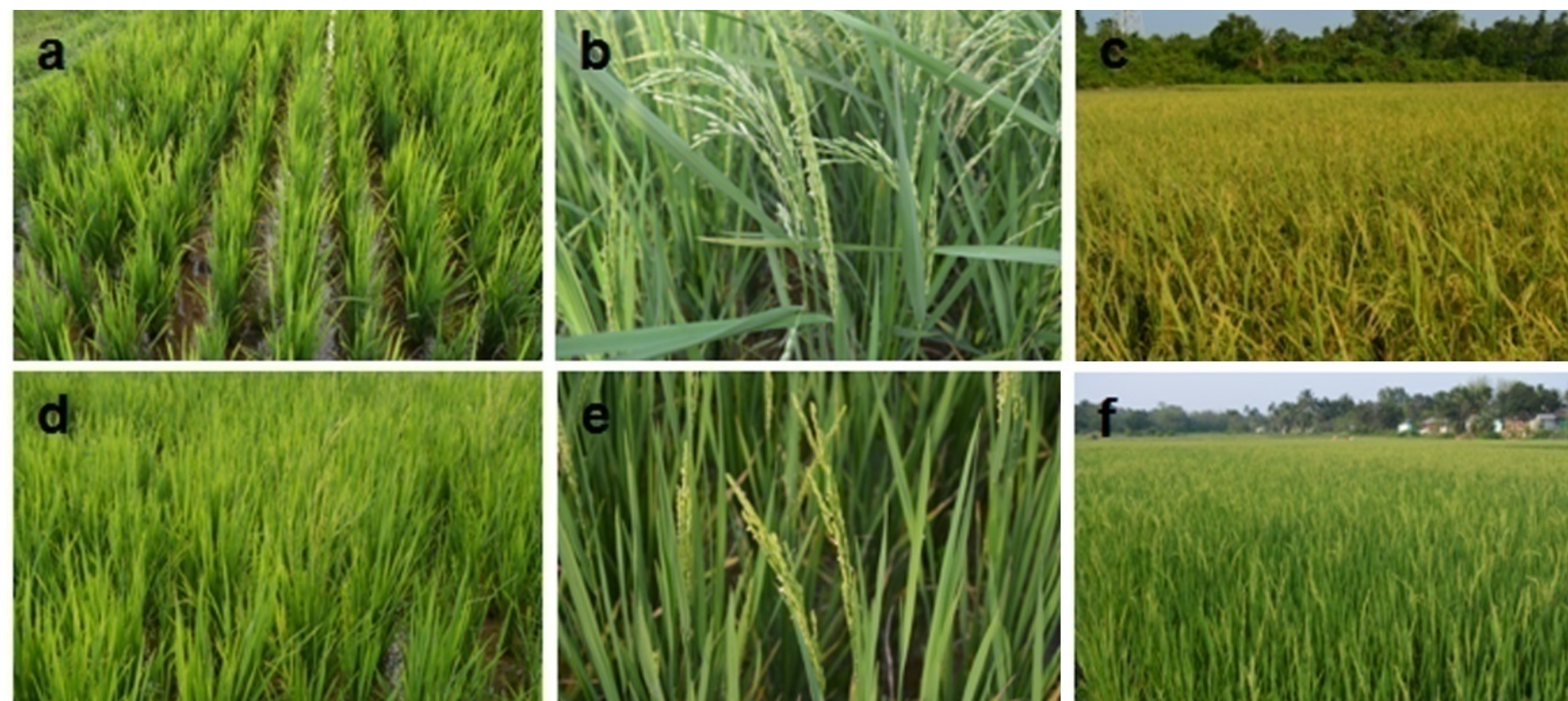

Fig. 1. Rice fields in Suryamaninagar and Teliamura of Tripura, Northeast India. (a-c) Rice plants growing in Suryamaninagar, (d-f) Rice fields and plants in Teliamura.

Table 1. AM fungi and DSE colonization (\%) in rice collected from two areas of Tripura

\begin{tabular}{ccccccccc}
\hline \multirow{2}{*}{ Month } & \multicolumn{4}{c}{ Suryamaninagar } & & \multicolumn{2}{c}{ Teliamura } \\
\cline { 2 - 8 } & RLA & RLV & RLH & RDSE & RLA & RLV & RLH & RDSE \\
\hline 1 & $0.00 \pm 0.00 \mathrm{a}$ & $8.44 \pm 1.43 \mathrm{a}$ & $31.74 \pm 3.12 \mathrm{a}$ & $15.30 \pm 2.22 \mathrm{a}$ & $0.00 \pm 0.00 \mathrm{a}$ & $1.26 \pm 0.61 \mathrm{a}$ & $27.11 \pm 4.71 \mathrm{a}$ & $17.18 \pm 3.75 \mathrm{a}$ \\
2 & $16.54 \pm 3.01 \mathrm{~b}$ & $13.71 \pm 3.40 \mathrm{~b}$ & $44.66 \pm 4.57 \mathrm{~b}$ & $21.20 \pm 2.90 \mathrm{a}$ & $14.00 \pm 2.04 \mathrm{~b}$ & $9.39 \pm 1.62 \mathrm{~b}$ & $39.14 \pm 2.87 \mathrm{~b}$ & $22.27 \pm 1.63 \mathrm{a}$ \\
3 & $31.62 \pm 0.92 \mathrm{c}$ & $19.72 \pm 0.88 \mathrm{c}$ & $74.49 \pm 1.34 \mathrm{c}$ & $20.67 \pm 1.03 \mathrm{a}$ & $25.38 \pm 0.97 \mathrm{c}$ & $21.42 \pm 1.17 \mathrm{c}$ & $70.08 \pm 1.17 \mathrm{c}$ & $24.40 \pm 0.99 \mathrm{a}$ \\
4 & $31.37 \pm 1.58 \mathrm{c}$ & $18.58 \pm 1.08 \mathrm{~b}$ & $62.27 \pm 1.83 \mathrm{~d}$ & $29.55 \pm 1.61 \mathrm{~b}$ & $23.06 \pm 3.06 \mathrm{c}$ & $18.21 \pm 2.74 \mathrm{c}$ & $53.54 \pm 4.97 \mathrm{~d}$ & $24.36 \pm 3.2 \mathrm{a}$ \\
\hline
\end{tabular}

Different alphabets differ significantly at $P<0.05$.

RLA= root length with arbuscules; RLV= root length with vesicles; RLH= root length with hyphae/hyphal coils; RDSE= root length with dark septate endophytes.

to the genus level and morphologically distinct types within each genus were designated as morphotypes.

\section{Data analysis}

Spore density (SD) was calculated in terms of number of spores in $50 \mathrm{~g}$ soil samples. Mean and standard error were calculated. The colonization data were subjected to analysis of variance (ANOVA) and the means were separated by Duncan test $(\mathrm{P}<0.05)$ using the software, Statistica 9.0.

\section{Results}

\section{Mycorrhizal structural features}

After staining of roots of rice plant from the first month sample showed the presence of vesicles, aseptate hyphae. Very few of them forming appressoria (Fig. 2 b \& c) on the epidermal layer of root which are connected to the entangled mass of extraradical hyphae (Fig. 2 a). Also some of the vesicles (Fig. $2 \mathrm{~h} \&$ i) and intracellular aseptate hyphae (Fig. $2 \mathrm{f} \& \mathrm{~g}$ ) within the root cortex were observed in the first month. However, no arbuscules were observed in the first month in the stained root samples. From second month onwards all the mycorrhizal structures such as hyphae, intracellular hyphae, vesicles and arbuscules (Fig. $2 \mathrm{l} \& \mathrm{~m}$ ) were observed. The presence of these structures confirms the colonization by AM fungi. The longitudinal running of the hyphae (Fig. $2 \mathrm{~d} \&$ e) in the intercellular cells of the cortex and from these hyphae certain hyphae protrudes and enters the cells more or less perpendicularly to forms arbuscules (Fig. 2 j, k \& $n$ ) which denotes the presence of Arum type of AM fungal morphology. Finally, young spores developed in the fourth month associated with the roots (Fig. 2 o).

The presence of septate hyphae running in frequent sections on the epidermal layer (Fig. 3 ae) and the occurrence of microsclerotia (Fig. $3 \mathrm{f}$ ) marks the colonization by DSE fungi. The cooccurrence of both AM and DSE fungi ensures dual colonization by two different fungal groups. 

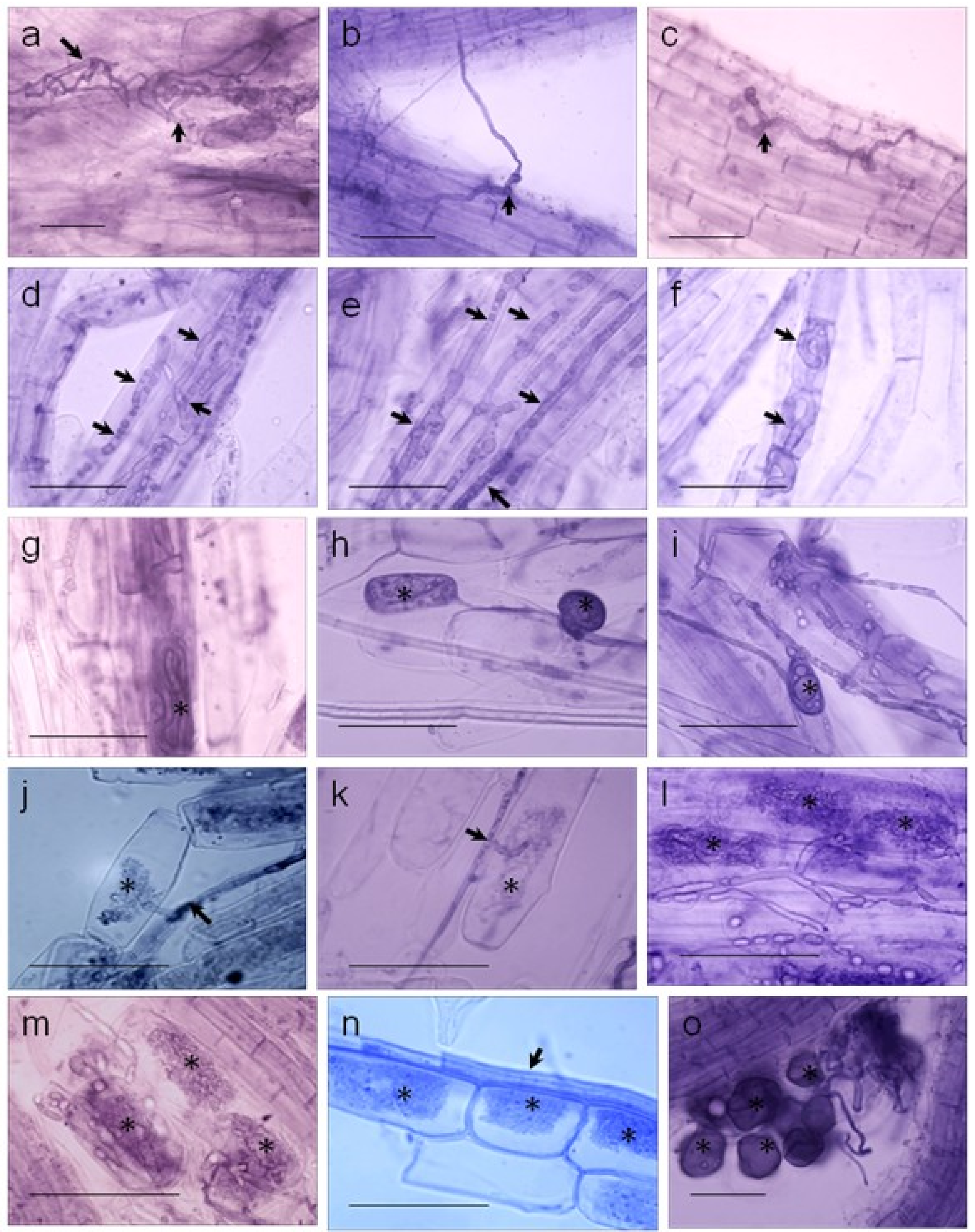

Fig. 2. Light microscopic images of Arbuscular mycorrhizal fungal colonization in the roots of rice. (a) Extraradical hyphae of AM attached with the root of rice. (b \& c) Appressoria in the epidermal layer of root. (d \& e) Intercellular hyphae in the root cortex of rice. (f \& $\mathbf{g}$ ) Intracellular hyphal coil of AM. (h \& i) Vesicles in the cortical layers. (J, k \& $\mathbf{n}$ ) Arum type of morphology. (l \& $\mathbf{m})$ Arbuscules with hyphae. (o) Young spores of AM fungi attached with roots. Scale bars: $a=300 \mu \mathrm{m} ; b$ \& $c=200 \mu \mathrm{m} ; d$ \& $e=150 \mu \mathrm{m} ; \mathrm{f}-\mathrm{i}=100 \mu \mathrm{m} ; j-\mathrm{n}=50 \mu \mathrm{m} ; \mathrm{o}=200 \mu \mathrm{m}$.

\section{Mycorrhizal colonization}

The degree of AM and DSE fungal colonization is depicted in (Table 1). Significant increase was observed in arbuscule, vesicles and hyphal percentages of AM from first to third month in both the samples collected from two sites. DSE 

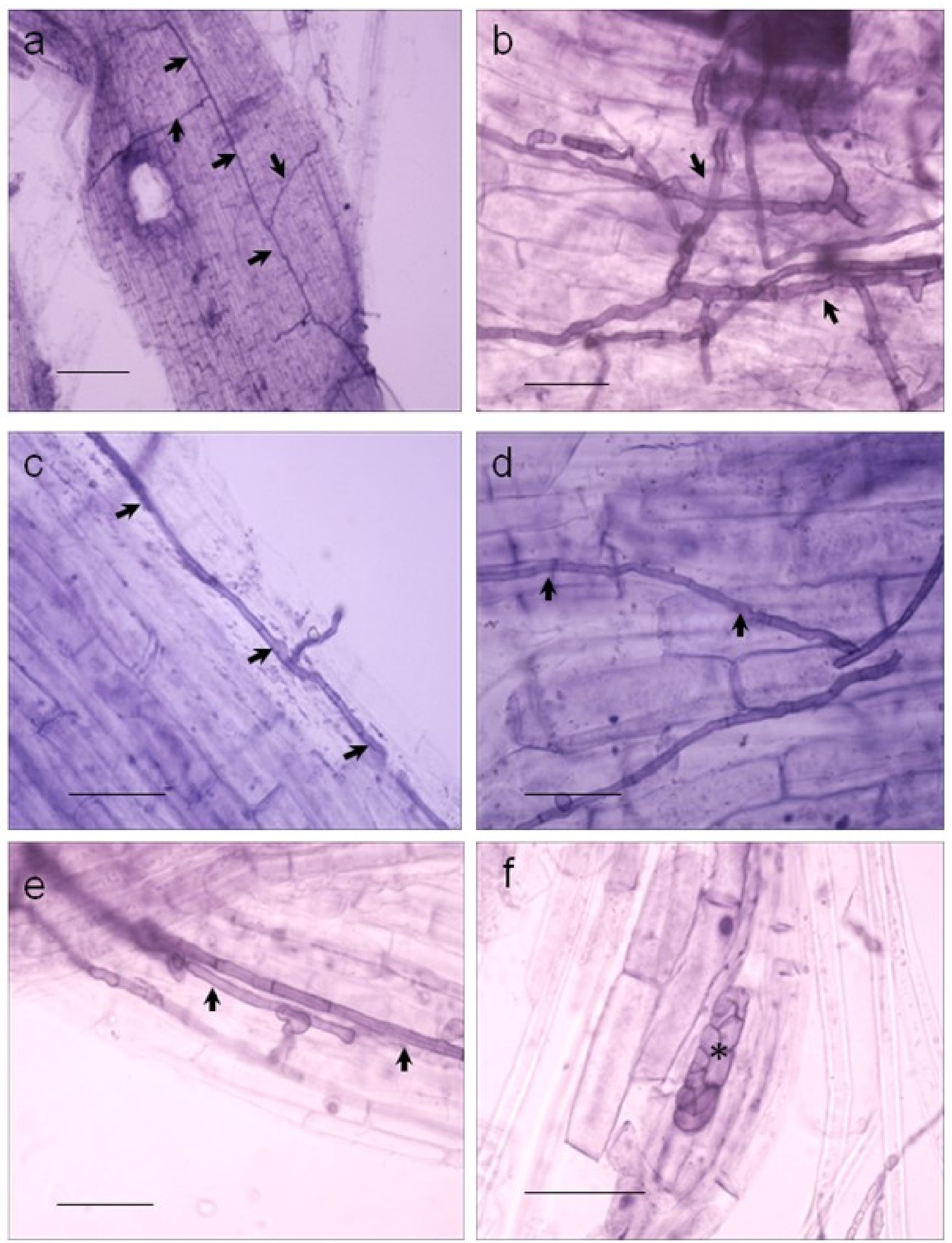

Fig. 3. Light microscopic images of Dark Septate Endophyte colonization in the roots of rice. (a-e) DSE hyphae in the root epidermal layer of rice. (f) Microsclerotia in the root epidermis. Scale bars: $a=200 \mu \mathrm{m} ; \mathrm{b}-\mathrm{e}=100 \mu \mathrm{m} ; \mathrm{f}=50 \mu \mathrm{m}$.

hyphal percentages do not differ significantly in first to third month. However, there was significant increase in the last month of root samples collected from Suryamaninagar. There was no significant increase in DSE percentages in the root samples of Teliamura. In the third month, AM colonization significantly enhanced in both the 
Table 2. AM fungi isolated from the rice fields of Tripura

\begin{tabular}{lcc}
\hline AM fungi & Suryamaninagar & Teliamura \\
\hline Gigaspora sp. 1 & + & - \\
Gigaspora sp. 2 & + & + \\
Glomus macrocarpum & + & - \\
Glomus sp. 1 & + & - \\
Glomus sp. 2 & - & - \\
Glomus sp. 3 & - & + \\
Glomus sp. 4 & + & + \\
Glomus sp. 5 & 07 & + \\
Rhizophagus diaphanus & $204 \pm 17.17$ & $307 \pm 40.73$ \\
Total number of species & + & + \\
Spore density/ 50g of soil & & \\
\hline
\end{tabular}

sites. AM hyphal colonization significantly differ in all the months between two sites (Fig. 3).

\section{AM fungal composition}

AM fungi extracted from two sites are depicted in Table 2. Spore density/50 g was higher in Teliamura than Suryamaninagar. A total of 9 AM morphotypes were recovered from two sites, of which, seven from Suryamaninagar and four from Teliamura.

\section{Discussion}

Most of the ecosystems harbour AM fungi as one of the main constituent of soil microbiota (17) and form symbiotic association with roots of most terrestrial plants including many agricultural crops (14). Colonization by native AM fungi in rice plant has been reported earlier (18). Partial dependency of upland rice on native AM fungi for phosphorus acquisition has also been reported (19). The occurrence of AM fungi at varying stages of growth of rice plants has been studied (20). In this present assessment the extent of mycorrhizal colonization varies in rice plants of two studied sites of Tripura. Dual colonization was observed during the different growth phases of rice plants. $\mathrm{AM}$ and DSE fungal colonization exhibited increasing trend upto the three month of rice plants from their planting time and then start declining. The possible reason for this may be the plants attained maturity after the fruiting phase and require a lesser amount of nutrients compared to the vegetative and reproductive phases of growth.

The fungal colonization percentage was found to be higher than the range given earlier (21) for contaminated and non-contaminated soils of rice plants. Ruiz-Sunchez et al. (22) observed growth pattern of rice plants inoculated with Azospirillum and AM fungi and proclaimed that dual colonization of AM and bacteria promote growth of rice plants. Watanarojanaporn et al. (23) studied AM fungal colonization pattern in different growth phases of rice plants which is in accordance with this present observation. There is an increasing trend in AM fungal colonization till the harvesting stage i.e, upto four month old rice plants which is in contrast to the result obtained in earlier study (24). The difference in AM colonization between two sites in the present study may be due to their high response to physico-chemical and biological conditions of the soil. For understanding the plant-fungus-soil interaction assessing the distribution and quantity of AM fungi is important (25). The colonization reported earlier (26) is lower than the present study.

In spite of vast significance of AM fungi, information on diversity and biology of these important soil fungi is very inadequate globally (27). AM fungal spore density of this present study is within the range specified (26) in various crop soils of Pakistan while Trindade et al. (28) postulated lower range of AM fungal spores in papaya plantations of Brazil. AM fungal inhabited in the rhizosphere may vary with host plant species (29). AM fungal taxa Glomus was highly abundant in the rhizosphere of rice plants and are in agreement with the results obtained earlier (30). The dominancy of Glomus species have also been reported by AM fungi occurring throughout the world $(31,32,33)$.Earlier workers also marked out that Glomus is the dominant genus occurring in Indian soil $(34,35)$ and may be attributed with their high adaptability to varied soil and temperature conditions and persist to exist in both acidic and alkaline soils (36). The copiousness of 


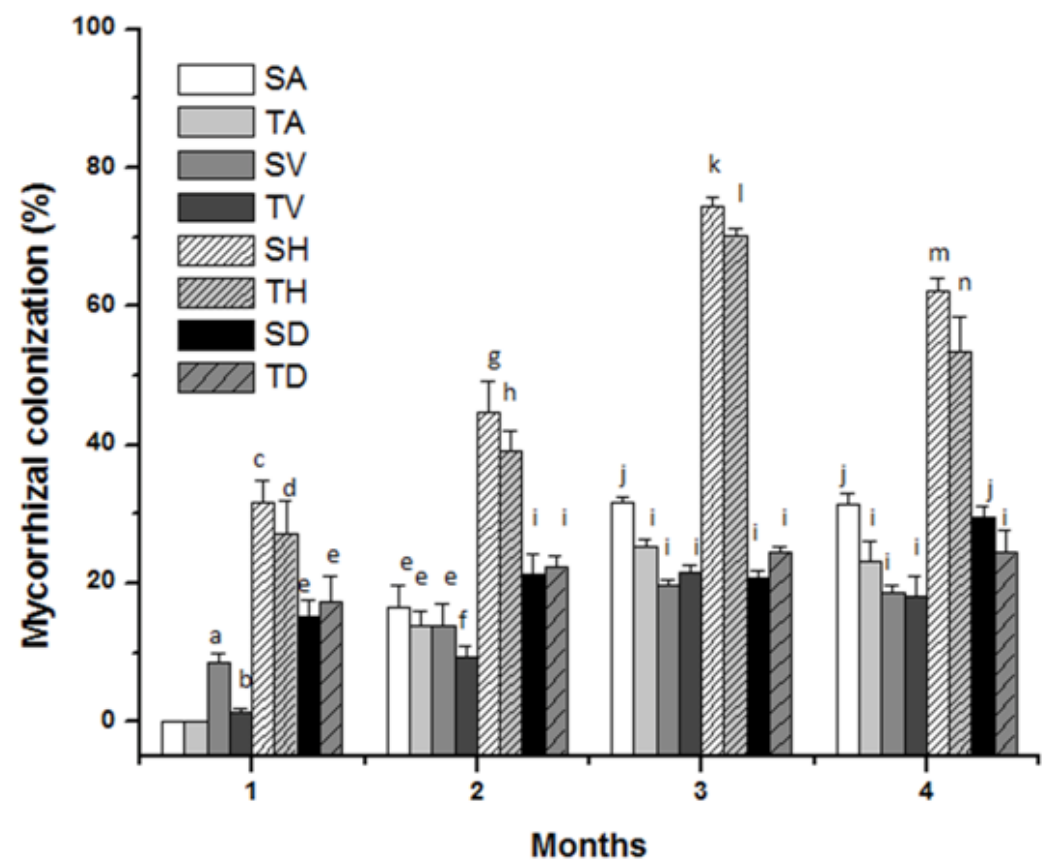

Fig. 4. Mycorrhizal structural colonization in rice from Suryamaninagar and Teliamura, Tripura, Northeast India.

SA - arbuscules from the roots of rice in Suryamaninagar; TA - arbuscules from the roots of rice in Teliamura; SV - vesicles from the roots of rice in Suryamaninagar; TV - vesicles from the roots of rice in Teliamura; SH - hyphae from the roots of rice in Suryamaninagar; TH - hyphae from the roots of rice in Teliamura; SD - DSE from the roots of rice in Suryamaninagar; TD - DSE from the roots of rice in Teliamura. Different alphabets differ significantly at $P<0.05$.

Glomus was also reported from these areas $(37,38,39,40)$.

\section{Conclusions}

The growth and yield of rice plants under field condition is greatly influenced by the native AM fungal composition. The degree of AM fungal colonization is showing an increasing trends upto the harvesting periods. However, an extensive study on AM fungi associated with rice plants need to be carried out under experimental conditions to underpin the exact role of AM fungi on the growth of rice plants. This study is an effort to make aware the local village farmers about the efficacy of these native AM mycobiota which can be harnessed for long term applications and preferable over chemical fertilizers leading to eco friendly organic farming. The present occurrence of these fungi from rice fields also indicates that they may have contributed to healthy production of rice which supports local livelihoods.

\section{Conflict of interest}

The authors declared that they have no conflict of interest.

\section{Author's Contribution}

PD and AKS designed the objectives and plan of work. SB, KC, AD and ARD carried out the work. $\mathrm{PD}$ and $\mathrm{KC}$ analysed the data. PD, KC and AKS wrote the manuscript.

\section{Acknowledgements}

The authors are thankful to Head, Department of Botany, Tripura University for providing the laboratory facilities. KC is grateful to Department of Science and Technology, Government of India for the INSPIRE fellowship.

\section{References}

1. Smith SE, Read DJ. Mycorrhizal symbiosis Acad. press, London. 2008.

2. Tinker PB. Effect of (vesicular-) arbuscular mycorrhizae on higher plants. In Symposium Society Exp Bio. 1975; 1 29: 325-349.

3. Gianinazzi S, Scheuepp H. Impact of arbuscular mycorrhiza on sustainable agriculture and natural ecosystems. Basel, 1994. https://doi.org/10.1007/978-3-0348-8504-1

4. Dickson S. The Arum-Paris continuum of mycorrhizal symbioses. New Phytol. 2004; 163: 187-200. https://doi.org/ 10.1111/j.1469-8137.2004.01095.x

5. Jumpponen A, Trappe JM. Dark septate endophytes: a review of facultative biotrophic root colonizing fungi. New Phytol. 1998; 140:295-310. https://doi.org/10.1046/j.14698137.1998.00265.X

6. Jumpponen A. Dark septate endophytes - are they mycorrhizal? Mycorrhiza 2001; 11: 207-211. https://doi.org/ $\underline{10.1007 / \mathrm{s} 005720100112}$

7. Mandyam K, Jumpponen A. Seeking the elusive function of the root colonizing dark septate endophytic fungi. Stud Mycol. $2005 ; \quad 53$ : $173-189$. https://doi.org/10.3114/sim.53.1.173

8. Mitra D, Guha J, Choudhuri SK. Studies in Botany. Moulik Library. Calcutta. 1968; Vol 2:708-711.

9. Allen MF. The ecology of arbuscular mycorrhizas: a look back into the 20th Century and a peek into the 21st. Mycol 
Res. 1996; 100:769-782. https://doi.org/10.1016/S09537562(96)80021-9

10. De Mars BG, Boerner REJ. Mycorrhizal dynamics of three woodland herbs of contrasting pathology along topographic gradients. Am J Bot. 1995;82: 1426-1431. https://doi.org/10.1002/j.1537-2197.1995.tb12680.x

11. Ilag LL, Rosales AM, Elazegui FA, Mew TW. Changes in the populations on infective endomycorrhizal fungi in a ricebased cropping system. Plant Soil. 1987; 103:67-73. https:// doi.org/10.1007/BF02370669

12. Yeasmin T, Zaman P, Rahman A, Absar N, Khanum NS. Arbuscular mycorrhizal fungus inoculum production in rice plants. African J Agri Res. 2008; 2:463-467.

13. Roy Das A, Talapatra K, Chakraborty K, Saha AK, Das P. A commercially available fabric whitener serves as a stain for detection of arbuscular mycorrhizal fungi in roots. Mycorrhiza News. 2015; 27(3): 2-4.

14. McGonigle TP, Miller MH, Evans DG, Fairchild GL, Swan JA. A method which gives an objective measure of colonization of roots by vesicular-arbuscular mycorrhizal fungi. New Phytol. 1990; 115: 495501.https://doi.org/10.1111/j.1469-8137.1990.tb00476.x

15. Gerdemann J W, Nicolson TW. Spores of mycorrhizal endogone species extracted from soil by wet-sieving and decanting method. Transac Brit Myco Soc. 1963;46: 235245. https://doi.org/10.1016/S0007-1536(63)80079-0

16. Koske R E, Tessier B. A convenient permanent slide mounting medium. Mycol. Soc. Am. News.1983; $134: 59$.

17. Oehl $\mathrm{F}$, Sieverding $\mathrm{E}$, Ineichen $\mathrm{K}$, Mader $\mathrm{P}$, Boller $\mathrm{T}$, Wiemken A. Impact of land use intensity on the species diversity of arbuscular mycorrhizal fungi in agroecosystems of Central Europe. Appl Environ Microbiol. 2003; 69: 2816-2824 https://doi.org/10.1128/AEM.69.5.2816-2824.2003

18. Maiti D, Variar M, Saha J. Colonization of upland rice by native VAM under rainfed mono cropped ecosystem. In: Roy AK, Sinha KK (eds) Recent advances in phyto pathological research, MD Publication, New Delhi. 1995; $45-51$.

19. Saha R, Saha J, Bhattacharya PM, Maiti D, Chowdhury S Arbuscular mycorrhizal responsiveness of two varieties in nutrient deficient laterite soil (abstr.). In: Proc Nat Conf on Mycorrhiza, Barkhatullah University, Bhopal. 1999; 28, 5-7 1999.

20. Dubey A, Mishra MK, Singh PK, Vyas D. Occurrence of AM fungi at varying stages of growth of rice plants. Proc Nat Acad Sci Ind. 2008; 78(1):51-55.

21. Zhang $\mathrm{XH}$, Wang YS, Lin AJ. Effects of arbuscular mycorrhizal colonization on the growth of upland rice (Oryza Sativa L.) in soil experimentally contaminated with $\mathrm{Cu}$ and Pb. J Clin Toxicol. 2011;3(3):1-5.

22. Ruiz-Sunchez M, Armada E, Garcia de Salamone IE, Arora R, Ruiz-Lozano JM,Azcon R. Azospirillum and arbuscular mycorrhizal colonization enhance rice growth and physiological traits under well-watered and drought conditions. J Plant Physiol. 2011; 168(10):1031-1037. https://doi.org/10.1016/j.jplph.2010.12.019

23. Watanarojanaporn $\mathrm{N}$, Boonkerd N, Tittabutr $\mathrm{P}$, Longtonglang A, Peter, J, Young W, Teaumroong N. Effect of rice cultivation systems on indigenous arbuscular mycorrhizal fungal community structure. Microbes Environ. $\quad 2013 ; \quad 28(3)$ : $316-324$ https://doi.org/10.1264/jsme2.ME13011

24. Bhattacharjee S, Sharma GD. The vesicular arbuscular mycorrhiza associated with three cultivars of rice (Oryza sativa L.). Indian J Microbiol. 2011; 51(3):377-383. https://doi.org/10.1007/s12088-011-0090-9

25. Becerra AG, Arrigo NM, Bartoloni N, Domínguez LS, Cofré MN. Arbuscular mycorrhizal colonization of Alnus acuminata Kunth in North western Argentina in relation to season and soil parameters. Cl Suelo (Argentina). 2007; 25: 7-13.

26. Sharif M, Moawad AM. Arbuscular mycorrhizal incidence and infectivity of crops in North West Frontier Province of Pakistan. Wrld J Agri. Sci. 2006; 2 (2): 123-132.

27. May TW. Documenting the Fungal Biodiversity of Australasia: from 1800 to 2000 and beyond. Aust Syst Bot. 2001; 14: 329-356. https://doi.org/10.1071/SB00013

28. Trindade AV, Siqueira J O, Luiz Stürmer S . Arbuscular mycorrhizal fungi in papaya plantations of Espírito Santo and Bahia, Brazil. Braz J Microbiol. 2006; 37: 283-289. https://doi.org/10.1590/S1517-83822006000300016

29. McGonigle TP, Fitter AH. Ecological specificity of vesiculararbuscular mycorrhizal associations. Mycol Res. 1990; 94: 120- 122. https://doi.org/10.1016/S0953-7562(09)81272-0

30. Lamont B. Mechanisms for enhancing the nutrient uptake in plants with particular reference to Mediterranean South Africa and Western Australia. Bot Rev. 1982; 48: 597-689. https://doi.org/10.1007/BF02860714

31. Koske RE. Gigaspora gigantean observations on the spore germination of a VA mycorrhizal fungus. Mycologia 1981;73 289https://doi.org/10.1080/00275514.1981.12021346

32. Blaszkowki J. Aculaospora cavernata (Endogonaceae) new species from Poland with pitted spores. Crypt Bot. 1989; 1: 201-207.

33. Talukdar NC, Germida JJ. Occurrence and isolation of vesicular arbuscular mycorrhizal fungi in cropped field soils of Saskatchewan, Canada. Can J Microbiol. 1993; 39: 567-575. https://doi.org/10.1139/m93-082

34. Muthukumar T, Udaiyan K. Arbuscular mycorrhizas of plants growing in Western Ghats region, Southern India. Mycorrhiza. $\quad 2000 ; \quad 9$ : 297-313. https://doi.org/10.1007/s005720050274

35. Bhattacharya S, Bagyaraj DJ. Arbuscular mycorrhizal fungi associated with Coffea arabica. Geobios. 2002; 29: 93-96.

36. Ho I. Vesicular arbuscular mycorrhizae of halophytic grasses in the Alvard desert of Oregon. Northwest Sci. 1987; 61: 148-151.

37. Debnath A, Karmakar P, Debnath S, Roy Das A, Saha AK, Das P. Arbuscular mycorrhizal and dark septate endophyte fungal association in some plants of Tripura, North-East India. Current Res Environ and Applied Mycol. 2015; 5(4):398-407. https://doi.org/10.5943/cream/5/4/12

38. Chakraborty K, Sinha S, Debnath A, Roy Das A, Saha AK, Das P. Arbuscular mycorrhizal fungal colonization in three different age groups of rubber plantations in Tripura, North-East India. Pl Path Quaran. 2016; 6(2):122131. https://doi.org/10.5943/ppq/6/2/2

39. Sinha S, Chakraborty K, Saha AK, Das P. Mycorrhizal colonization in plants from selected home garden of Tripura. J Mycopathol Res. 2016; 54(3): 349-353.

40. Debnath A, Sinha S, Talapatra K, Chakraborty K, Saha AK, and Das P. Comparison of arbuscular mycorrhizal colonization and diversity of two different rubber plantations of Tripura, northeast India. Trends Fron Ar Pl Sci Res. 2017; 239- 247. 